\title{
Synthesis of Water-Soluble Phosphinophenol for Traceless Staudinger Ligation
}

Samuel H. Weisbrod, Andreas Marx*

Department of Chemistry and Konstanz Research School Chemical Biology, University of Konstanz, 78457 Konstanz, Germany

Fax +49(7531)885140; E-mail: andreas.marx@uni-konstanz.de

\begin{abstract}
The traceless Staudinger ligation can be mediated in water without organic co-solvents if charged groups render the phenylphosphine reagent water soluble. Here the synthesis of a new water-soluble phosphine is presented based on a diphenylphosphinophenol reagent. Staudinger ligation with this reagent and azido glycine amide showed conversion of $77 \%$.
\end{abstract}

Key words: amide, phenol, Staudinger ligation, conjugation, phosphine

The Staudinger ligation is a bioorthogonal conjugation reaction which needs no catalyst to proceed. ${ }^{1}$ Thus it has been employed for in vitro and in vivo labeling of several biomolecules as carbohydrates, proteins, and nucleic acids. ${ }^{2}$ Developed by Bertozzi in $2000^{3}$ the reaction is based on the Staudinger reduction, wherein an azide is reduced by a phosphine via an iminophosphorane intermediate. ${ }^{4}$ In the ligation reaction an intramolecular acetylation of the iminophosphorane takes place, and after hydrolysis an amide bond is formed. ${ }^{5}$ In the traceless variant the arylphosphine is part of the leaving group, and just a native amide bond between the ligation partners is formed (Scheme 1). ${ }^{6}$ Thus the traceless Staudinger ligation is especially useful to ligate oligopeptides to form larger polypeptides or peptide conjugates. ${ }^{7,8}$

There are mainly two types of traceless Staudinger phosphines, one is based on (diphenylphosphino)methanethiol 2 and has been developed by Raines et al., ${ }^{9}$ the other de-<smiles>[R1][N-][PH+](c1ccccc1OC([R])=O)c1ccccc1P(c1ccccc1)c1ccccc1OC([R])=O</smiles><smiles>[R]NC(=O)[PH2+]</smiles>

Scheme 1 Putative mechanism of traceless Staudinger ligation veloped by Bertozzi et al. consists of (diphenylphosphino)phenol 3 (Figure 1, 1 nontraceless Staudinger ligation phosphine for comparison). ${ }^{10}$ Both show comparable reaction kinetics in ligation reactions with small molecules. ${ }^{6}$ For labeling of biomolecules the water solubility of the phosphine reagent is critical because the ligation reaction has to proceed in water. In case of the methanethiol derivative $\mathbf{2}$ this problem has been extensively investigated by adding negatively or positively charged moieties to the phenyl rings at different positions. ${ }^{8,11}$ It turned out that $N, N$-dimethylbenzylamine-substituted phosphinomethanethiols gave best yields in Staudinger ligation reactions performed in water. ${ }^{11}$<smiles>[R]C(=O)Oc1ccccc1P(c1ccc(CN(C)C)cc1)c1ccc(CN(C)C)cc1</smiles>

Figure 1 Overview of phosphines for Staudinger ligations

Here, we target on the phosphinophenol 3 which has been used for peptide conjugation and glycoconjugation to proteins so far. ${ }^{12}$ We reasoned that tertiary benzylic amines should facilitate easy synthesis using inexpensive starting materials. The modification should be placed at the unsubstituted phenyl rings of phosphinophenol 3 leading to the structure of $\mathbf{4}$. Additionally, these positive charged groups best mediated the Staudinger ligation in case of the methanethiol derivatives.

Our synthesis starts with the protection of phenol with ethyl vinyl ether (EVE) and catalytic amounts of pyridinium $p$-toluenesulfonate (PPTS, Scheme 2). ${ }^{13}$ This protecting group is also mediating directed metalation required for subsequent directed ortho metalation (DOM). The next step was the selective introduction of the phosphor moiety in a DOM reaction with diethyl chlorophosphite. The $N, N$-dimethylbenzylamine moiety was introduced by halogen-lithium exchange using bromide 7 and subsequent addition to phosphonite 6 . The yield was $66 \%$ and the main side products were butyl-substituted phosphines. Bromide 7 can be easily synthesized starting from $p$-bromo- 
benzyl bromide and is also commercially available. The final deprotection of the phenol was performed in $1 \mathrm{M}$ aqueous $\mathrm{HCl}$ since catalytic amounts of PPTS were not sufficient presumably due to the presence of the tertiary amines. The final phosphinophenol 9 is water soluble and stable to air at least for one week in solution as checked by ${ }^{31} \mathrm{P}$ NMR.
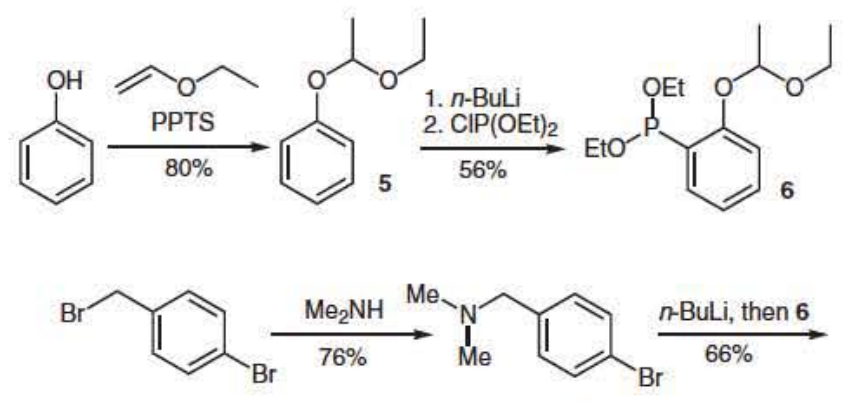<smiles>CCOC(C)Oc1ccccc1P(c1ccc(CN(C)C)cc1)c1ccc(CN(C)C)cc1</smiles>

Scheme 2 Synthesis of water-soluble phosphinophenol

Next, the Staudinger ligation with this new water-soluble phosphinophenol was investigated. Therefore compound 9 has been acetylated in pyridine using acetic anhydride yielding phosphine $\mathbf{1 0}$ which should be capable to transfer the acyl group in a Staudinger ligation reaction. Watersoluble azidoglycine amide has been chosen as ligation partner. To increase the water solubility of acetylated phosphinophenol 10 the TFA salt was used which is hygroscopic and well soluble in water $(>0.1 \mathrm{M})$. The reaction proceeded slowly as monitored by ${ }^{1} \mathrm{H}$ NMR, but after 30 hours conversion stopped, and the product was formed in $77 \%$ yield (Scheme 3 ).

In summary, here we present a five-step synthesis of a water-soluble, unsymmetrically substituted triphenylphosphine-based reagent for traceless Staudinger ligation in water at neutral $\mathrm{pH}$. The employed phosphine 9 is

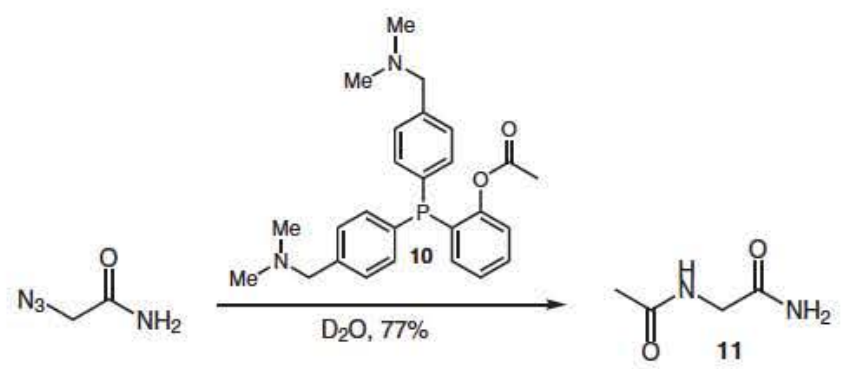

Scheme 3 Investigated traceless Staudinger ligation in water stable towards oxidation at least for one week in solution. Although the triphenylphosphine core is highly hydrophobic, the two introduced tertiary amines increase the water solubility of the phosphine sufficiently and thus, reactions in water without organic co-solvents are possible. The conversion of the Staudinger ligation reaction is comparable to the water-soluble methanethiol derivatives, ${ }^{11}$ which seem to be more susceptible to oxidation since only two phenyl rings stabilize the phosphine.

\section{Diethyl Arylphosphonite 6}

To a solution of EVE-protected phenol $(2.99 \mathrm{~g}, 18.0 \mathrm{mmol})$ in anhyd THF $n$-BuLi (1.6 M in hexane, $12.4 \mathrm{~mL}, 19.9 \mathrm{mmol}$ ) was added dropwise at $0{ }^{\circ} \mathrm{C}$, stirred for $1.5 \mathrm{~h}$ hours at $0{ }^{\circ} \mathrm{C}$ and further $1.5 \mathrm{~h}$ at r.t. The dark solution was added to a cooled $\left(-78^{\circ} \mathrm{C}\right)$ solution of $(\text { EtO })_{2} \mathrm{CIP}$ in THF $(10 \mathrm{~mL})$ and stirred $16 \mathrm{~h}$ with warming to r.t. After evaporation of THF the residue was distilled in vacuo (1 mbar, $\left.104^{\circ} \mathrm{C}\right)$ and isolated as colorless liquid $(2.9 \mathrm{~g}, 56 \%) .{ }^{1} \mathrm{H}$ NMR (400 $\left.\mathrm{MHz}, \mathrm{CDCl}_{3}\right): \delta=7.63(1 \mathrm{H}, \mathrm{m}), 7.31(1 \mathrm{H}, \mathrm{m}), 7.07(\mathrm{dd}, J=8.0$, $4.1 \mathrm{~Hz}, 1 \mathrm{H}), 7.01(\mathrm{t}, J=7.4 \mathrm{~Hz}, 1 \mathrm{H}), 5.46(\mathrm{q}, J=5.3 \mathrm{~Hz}, 1 \mathrm{H}), 3.92$ $(\mathrm{m}, 2 \mathrm{H}), 3.80(\mathrm{~m}, 3 \mathrm{H}), 3.56(\mathrm{~m}, 1 \mathrm{H}), 1.51(\mathrm{~d}, J=5.4 \mathrm{~Hz}, 3 \mathrm{H})$, $1.25(\mathrm{dd}, J=12.9,6.9 \mathrm{~Hz}, 7 \mathrm{H}), 1.18(\mathrm{t}, J=7.1 \mathrm{~Hz}, 3 \mathrm{H}) .{ }^{13} \mathrm{C}$ NMR $\left(100 \mathrm{MHz}, \mathrm{CDCl}_{3}\right): \delta=159.5$ (d), $131.5,130.6$ (d), 130.1 (d), 121.7, $115.3,99.5,63.0$ (d), 62.8 (d), 60.8, 20.1, 17.4, 17.3, 15.4. ${ }^{31}$ P NMR $\left(162 \mathrm{MHz}, \mathrm{CDCl}_{3}\right): \delta=150.3$.

\section{Phosphine 8}

To a solution of compound 7 ( $3.43 \mathrm{~g}, 16 \mathrm{mmol})$ in anhyd THF (20 $\mathrm{mL}), n$-BuLi (1.6 M in hexane, $10 \mathrm{~mL}, 16 \mathrm{mmol}$ ) was added dropwise at $-78{ }^{\circ} \mathrm{C}$ and stirred for $1 \mathrm{~h}$. Diethyl arylphosphonite 6 (2.15 $\mathrm{g}, 7.5 \mathrm{mmol})$ in THF $(10 \mathrm{~mL})$ was added dropwise and stirred for 20 h with warming to r.t. and quenched with distilled $\mathrm{H}_{2} \mathrm{O}(10 \mathrm{~mL})$. After phase separation the water layer was extracted with $\mathrm{CH}_{2} \mathrm{Cl}_{2}$ $(2 \times 10 \mathrm{~mL})$, and the combined organic phases were dried $\left(\mathrm{MgSO}_{4}\right)$ and concentrated in vacuo. The residue was purified by flash column chromatography (EtOAc, then $2 \% \mathrm{MeOH}$ in $\mathrm{CH}_{2} \mathrm{Cl}_{2}$ containing $\left.1 \% \mathrm{Et}_{3} \mathrm{~N}\right)$ to afford triarylphosphine $8(2.29 \mathrm{~g}, 66 \%)$ as slightly yellow oil. ${ }^{1} \mathrm{H}$ NMR $\left(400 \mathrm{MHz}, \mathrm{CDCl}_{3}\right): \delta=7.25-7.17(\mathrm{~m}, 9 \mathrm{H})$, 7.04 (dd, $J=7.4,4.4 \mathrm{~Hz}, 1 \mathrm{H}), 6.80$ (t, $J=7.4 \mathrm{~Hz}, 1 \mathrm{H}), 6.63(\mathrm{~m}, 1$ H), $5.25(\mathrm{q}, J=5.3 \mathrm{~Hz}, 1 \mathrm{H}), 3.42-3.31(\mathrm{~m}, 1 \mathrm{H}), 3.36(\mathrm{~s}, 4 \mathrm{H}), 3.23$ $(\mathrm{m}, 1 \mathrm{H}), 2.18(\mathrm{~s}, 12 \mathrm{H}), 1.14(\mathrm{~d}, J=5.4 \mathrm{~Hz}, 3 \mathrm{H}), 0.98(\mathrm{t}, J=7.1$ $\mathrm{Hz}, 3 \mathrm{H}) .{ }^{13} \mathrm{C}$ NMR (100 MHz, $\mathrm{CDCl}_{3}$ ): $\delta=158.4$ (d), 134.3, 134.1, $134.0,133.8,133.3$ (d), 130.0, 129.2 (d), 129.1 (d), 124.4 (d) 121.7, $114.5,98.8,64.1,59.6,45.3,19.3,15.2$. ${ }^{31} \mathrm{P}$ NMR (162 MHz, $\mathrm{CDCl}_{3}$ ): $\delta=-17.2$. ESI-HRMS: $m / z$ calcd for $\mathrm{C}_{28} \mathrm{H}_{38} \mathrm{~N}_{2} \mathrm{O}_{2} \mathrm{P}[\mathrm{M}+$ $\mathrm{H}]^{+}: 465.2665$; found: 465.2664 .

\section{Phosphinophenol 9}

Phosphine 8 ( $1.10 \mathrm{~g}, 2.37 \mathrm{mmol})$ was dissolved in aq $\mathrm{HCl}(1 \mathrm{M}, 30$ $\mathrm{mL}$ ) and stirred for $16 \mathrm{~h}$ at r.t. Water was evaporated and the residue chromatographed with RP-MPLC (Büchi C18 column, linear gradient $\mathrm{H}_{2} \mathrm{O}-\mathrm{MeCN}, 0.1 \%$ TFA). The free amino compound was isolated by extraction of sat. $\mathrm{NaHCO}_{3}$ solution $(50 \mathrm{~mL})$ with $\mathrm{CH}_{2} \mathrm{Cl}_{2}$ $(3 \times 30 \mathrm{~mL})$ and yielded $0.45 \mathrm{~g}, 48 \% .{ }^{1} \mathrm{H} \mathrm{NMR}\left(400 \mathrm{MHz}, \mathrm{CDCl}_{3}\right)$ : $\delta=7.28-7.20(\mathrm{~m}, 8 \mathrm{H}), 7.16(\mathrm{~m}, 1 \mathrm{H}), 6.76-6.67(\mathrm{~m}, 3 \mathrm{H}), 3.42(\mathrm{~s}$, $4 \mathrm{H}), 2.21$ (s, $12 \mathrm{H}) .{ }^{13} \mathrm{C}$ NMR (100 MHz, $\left.\mathrm{CDCl}_{3}\right): \delta=159.6$ (d), $135.7,135.6,134.1,133.9,133.7,132.0$ (d), 130.4, 129.3 (d), 129.2 (d), 123.2 (d) $119.8,115.3,98.8,63.9,45.9 .{ }^{31} \mathrm{P}$ NMR (162 MHz, $\mathrm{CDCl}_{3}$ ): $\delta=-20.0$. ESI-HRMS: $m / z$ calcd for $\mathrm{C}_{24} \mathrm{H}_{30} \mathrm{~N}_{2} \mathrm{OP}[\mathrm{M}+$ $\mathrm{H}]^{+}:$393.2090; found: 393.2084 .

\section{Acetylphosphinophenol 10}

To a solution of phosphine 9 ( $50 \mathrm{mg}, 0.12 \mathrm{mmol})$ in anhyd pyridine $(1 \mathrm{~mL}) \mathrm{Ac}_{2} \mathrm{O}(14 \mu \mathrm{L}, 0.15 \mathrm{mmol})$ was added and stirred for $2 \mathrm{~h}$. Af- 
ter evaporation of solvents the residue was extracted with $\mathrm{CH}_{2} \mathrm{Cl}_{2}$ $(3 \times 10 \mathrm{~mL})$ from sat. $\mathrm{NaHCO}_{3}$ solution $(20 \mathrm{~mL})$ and further purified by RP-MPLC (Büchi C18 column, linear gradient $\mathrm{H}_{2} \mathrm{O}-\mathrm{MeCN}$, $0.1 \%$ TFA) to yield $36 \mathrm{mg}, 66 \% .{ }^{1} \mathrm{H}$ NMR $\left(400 \mathrm{MHz}, \mathrm{D}_{2} \mathrm{O}\right): \delta=$ 7.42-7.30 (m, $9 \mathrm{H}), 7.14(\mathrm{~m}, 1 \mathrm{H}), 7.07(\mathrm{~m}, 1 \mathrm{H}), 6.88(\mathrm{~m}, 1 \mathrm{H}), 4.32$ (s, $4 \mathrm{H}), 2.78$ (s, $12 \mathrm{H}), 1.94$ (s, $3 \mathrm{H}) .{ }^{31} \mathrm{P}$ NMR $\left(162 \mathrm{MHz}, \mathrm{D}_{2} \mathrm{O}\right)$ : $\delta=-18.8$. ESI-HRMS: $m / z$ calcd for $\mathrm{C}_{26} \mathrm{H}_{32} \mathrm{~N}_{2} \mathrm{O}_{2} \mathrm{P}[\mathrm{M}+\mathrm{H}]^{+}$: 435.2196; found: 435.2190 .

\section{Staudinger Ligation}

TFA salt of phosphine $\mathbf{1 0}(60 \mu \mathrm{mol})$ and azidoglycine amide (78 $\mu \mathrm{mol})$ were combined in $\mathrm{D}_{2} \mathrm{O}(0.8 \mathrm{~mL})$ and the reaction monitored by ${ }^{1} \mathrm{H}$ NMR. Conversion has been determined by peak integration.

\section{Acknowledgment}

The authors would like to thank DFG (SPP 1243) for financial support.

\section{References}

(1) Köhn, M.; Breinbauer, R. Angew. Chem. Int. Ed. 2004, 43, 3106.

(2) (a) Weisbrod, S. H.; Marx, A. Chem. Commun. 2007, 1828. (b) Laughlin, S. T.; Bertozzi, C. R. Nat. Protoc. 2007, 2 , 2930. (c) Reddie, K. G.; Seo, Y. H.; Muse Iii, W. B.; Leonard, S. E.; Carroll, K. S. Mol. Biosyst. 2008, 4, 521. (d) Stabler, C. L.; Sun, X. L.; Cui, W.; Wilson, J. T.; Haller,
C. A.; Chaikof, E. L. Bioconjugate Chem. 2007, 18, 1713. (e) Verdoes, M.; Florea, B. I.; Hillaert, U.; Willems, L. I.; van der Linden, W. A.; Sae-Heng, M.; Filippov, D. V.; Kisselev, A. F.; van der Marel, G. A.; Overkleeft, H. S. ChemBioChem 2008, 9, 1735. (f) Yanagisawa, T.; Ishii, R.; Fukunaga, R.; Kobayashi, T.; Sakamoto, K.; Yokoyama, S. Chem. Biol. 2008, 15, 1187.

(3) Saxon, E.; Bertozzi, C. R. Science 2000, 287, 2007.

(4) Staudinger, H.; Meyer, J. Helv. Chim. Acta 1919, $2,635$.

(5) Lin, F. L.; Hoyt, H. M.; Van Halbeek, H.; Bergman, R. G.; Bertozzi, C. R. J. Am. Chem. Soc. 2005, 127, 2686.

(6) Soellner, M. B.; Nilsson, B. L.; Raines, R. T. J. Am. Chem. Soc. 2006, 128, 8820 .

(7) (a) Kleineweischede, R.; Hackenberger, C. P. Angew. Chem. Int. Ed. 2008, 47, 5984. (b) Liu, L.; Hong, Z. Y.; Wong, C. H. ChemBioChem 2006, 7, 429.

(8) Tam, A.; Soellner, M. B.; Raines, R. T. J. Am. Chem. Soc. 2007, 129, 11421.

(9) Nilsson, B. L.; Kiessling, L. L.; Raines, R. T. Org. Lett. 2001, 3, 9 .

(10) Saxon, E.; Armstrong, J. I.; Bertozzi, C. R. Org. Lett. 2000, 2, 2141 .

(11) Tam, A.; Raines, R. T. Bioorg. Med. Chem. 2009, 17, 1055.

(12) (a) Merkx, R.; Rijkers, D. T. S.; Kemmink, J.; Liskamp, R. M. J. Tetrahedron Lett. 2003, 44, 4515. (b) Grandjean, C.; Boutonnier, A.; Guerreiro, C.; Fournier, J.-M.; Mulard, L. A. J. Org. Chem. 2005, 70, 7123.

(13) Müller, C.; Ackerman, L. J.; Reek, J. N.; Kamer, P. C.; van Leeuwen, P. W. J. Am. Chem. Soc. 2004, 126, 14960. 